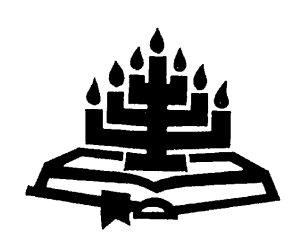

\title{
Oorvloedige liefde en konflikhantering: basisteoretiese perspektiewe uit Filippense
}

\author{
J. Pretorius \& B.J. de Klerk \\ Skool vir Kerkwetenskappe \\ Potchefstroomse Universiteit vir $\mathrm{CHO}$ \\ POTCHEFSTROOM \\ e-pos: kwsbjdk@puknet.puk.ac.za \\ e-pos: jacob@linden.org.za
}

\begin{abstract}
Abundant love and conflict management: Basis-theoretical perspectives from Philippians

The management of conflict in the process of building the Lord's church remains an issue in need of basis-theoretical guidelines based upon Scripture. The rhetorical analyses of Philippians during the past decade have brought about a better understanding of the structure and theme of the letter, but have failed to point out the performative effect of the paradigm "behind" the compilation of the letter. This paradigm (here referred to as "the abundant love of Christ") is not only mentioned in the letter itself, but the method of discourse analysis used in this article also reveals the impact of this love illustrated by the way that Pauls deals with various kinds of conflict. A more detailed analysis of the introduction of the letter (1:311, esp. v. 9-11) clearly underscores the existence and importance of Christ's love in Paul's writings and for the Philippians. Although the members of the Philippian congregation were partners in the furthering of the gospel, they missed Paul's mindset of love to a great extent. Through excellent rhetorical techniques this letter inspires the reader of today to use Paul's mindset in contemporary conflict management. The existence of such a mindset can be evaluated by means of empirical questions for the purposes of practical theology.
\end{abstract}


Opsomming

Oorvloedige liefde en konflikhantering: basisteoretiese perspektiewe uit Filippense

Konflikbestuur in die opbou van die kerk van die Here noodsaak basisteoretiese riglyne wat op die Skrif gegrond is. Die retoriese analises van Filippense wat gedurende die afgelope dekade onderneem is, het 'n beter begrip vir die struktuur en tema van die brief gelewer, maar kon nie daarin slaag om die verwysingsraamwerk of paradigma wat onderliggend aan die brief is, te ontgin nie. Die paradigma waarna in hierdie artikel verwys word as die "oorvloedige liefde van Christus", word nie net eksplisiet in die brief genoem nie, maar die analise wat in hierdie artikel gebruik word, openbaar die impak van die liefde soos dit aangedui word in die wyse waarop Paulus die verskillende soorte konflik in die gemeente hanteer. ' $n$ Meer gedetailleerde analise van die inleiding van die brief (1:3-11) wys op oortuigende wyse die bestaan en belang van Christus se liefde vir die Filippense aan. Hoewel die lede van die gemeente in Filippi deelgenote in die uitdra van die evangelie was, het hulle nie Paulus se fokus op liefde ten volle begryp nie. Deur uitmuntende retoriese tegnieke inspireer hierdie brief die hedendaagse leser om Paulus se fokus in die eietydse bestuur van konflik te gebruik. Die bestaan van hierdie fokus kan geëvalueer word deur middel van empiriese vrae vir die doel van die beoefening van praktiese teologie.

\section{Inleiding en metode}

Die afgelope dekade se wetenskaplike besinning oor die struktuur en tema van Filippense kan baie bydra tot die beter verstaan van die brief, maar dit alleen is onvoldoende vir insig in die bedoeling van die skrywer. Die onderliggende verwysingsraamwerk of paradigma van die brief is nog grootliks onontgin. In hierdie artikel word na hierdie paradigma verwys as die oorvloedige liefde van Jesus. Die ondersoek in hierdie artikel fokus op die impak van Jesus se oorvloedige liefde op Paulus se gesindheid en optrede in 'n konfliksituasie. Die sentrale vraag wat in hierdie artikel aan die orde kom is: In hoeverre is die impak van die liefde van Jesus ook onontbeerlik vir die hantering van konflik in die moderne gemeentebouproses?

Wat metode betref, sal eerstens aandag gegee word aan die struktuur en sentrale boodskap van Filippense. Hierna sal die gesindheid van die skrywer, Paulus, in fyner besonderhede ondersoek word. Laastens sal deur enkele vrae gesuggereer word hoe die impak van Jesus se liefde vandag steeds die deurslag in konflikhantering moet gee. 
Vir die ondersoek na die struktuur en sentrale boodskap, sal onder andere van die retories-kritiese metode gebruik gemaak word. Die waarde van hierdie metode is dat gepoog word om die invloed wat die teks se samestelling en tegnieke op die leser/hoorder het te verreken (vgl. Van Deventer, 1999:451-457; Deist, 1994:170 en Hayes \& Holladay, 1987:73-80). Die wetenskaplike bydraes wat hier bespreek word, openbaar tog ook 'n groot leemte: die liefdesgesindheid van die skrywer word nie behoorlik verreken en ontgin nie. Hierdie gesindheid is nie slegs "agter" die tema verskuil nie, maar word ook in die teks self aangekondig en beïnvloed die res van die brief. Daarom fokus hierdie artikel veral op die verstaan en uitwerking van Filippense 1:3-11 (veral vers 9-11), omdat hierdie verse regstreeks die liefdesgesindheid van die skrywer as vertrekpunt van die brief neem.

\section{Die tema en struktuur van Filippense}

\subsection{Inleidend: uiteenlopende verklaringsmetodes}

Skrifkritiese verklaringsmetodes het die laaste twee dekades deur verskillende fases beweeg. Die histories-kritiese metodologie is volgens Aspan grootliks onttroon (vgl. Pretorius, 1995:274) en moes vir veral die retoriese kritiek plek maak. Hierdie verskuiwing plaas 'n groter fokus op die teks self, veral aan die hand van diskoersanalise (vgl. Reed, 1999). Ten spyte van skerp meningsverskil tussen skrywers ${ }^{1}$, is die ooreenkomste oor die sentrale boodskap opvallend. In die onderstaande paragrawe word enkele grepe op Filippense aangedui en beredeneer ten einde hierdie ooreenkomste aan te toon en 'n leemte vir verdere ondersoek te motiveer.

\subsection{Pretorius se bespreking van Wick}

In sy bespreking van Wick (1994) se navorsing, open Pretorius (1998: 552-560) bruikbare perspektiewe ten opsigte van die verstaan van retoriese elemente in Filippense. Wick identifiseer met behulp van struktuurmerkers (soos ooreenkomste in woordeskat, styl en vorm) vyf parallelle pare of eenhede (elk met 'n eie tema) wat in 'n makroparallelisme saamgevoeg is (Pretorius, 1998:555-556). Hierdie struktuuranalise bring veral twee belangrike verstaansaspekte na vore wat tot 'n belangrike konklusie lei:

- Die Christus-himne (2:5-11) as selfstandige komponent versteur die patroon van parallelle diskoerse tot so mate dat dit formeel en

1 Vgl. Porter en Reed (1998:213-231) se kritiek op Luter, en Lee en Combrink se kommentaar op Schenk (vgl. Porter \& Reed, 1989:135-146). 
tematies, sentraal in die hele brief uitstaan. In die himne self, is die kruis weer sentraal (vgl. Pretorius, 1998:554).

- Die sogenaamde breuk tussen 3:1a en 3:1b word verklaar deurdat 3:1a en 3:1b juis die saambindende skakel tussen die twee pare van vyf elk is. Vers 3:1a rond die eerste vyf pare af deur op "blydskap" as 'n gevolg te wys. Met 3:1b word die volgende vyf pare ingelei en wil Paulus deur herhaling weer geloofsekerheid (in die kruis) bevorder (Pretorius, 1998:554-555, vgl. Venter, 1997:336).

Die "selfontlediging van Christus" (vgl. die himne) en die "oproep tot blydskap" as twee teologiese sentra, word daarom omvat in een grond-

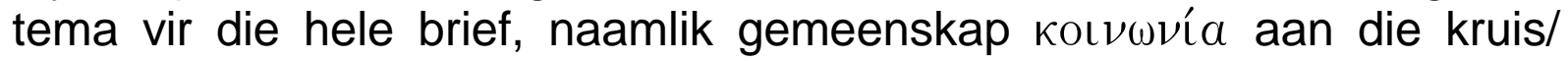
evangelie (aldus Wick, aangehaal deur Pretorius, 1998:557). Hierdie grondtema word egter as 'n "leading viewpoint of faith" (eerder as 'n sentrale tema) beskou (vgl. Pretorius, 1998:556). Regdeur die brief is daar 'n duidelike identifikasie ("association") met die voorbeeld van Christus en gemeenskap met sy evangelie (Pretorius, 1998:557).

\subsection{Davis}

Soos Wick (2.2) identifiseer Davis (1999:151-156) diskoerse met bepaalde temas, en wys hy hoe die temas 'n konsentriese struktuur vorm. In die danksegging (1:3-11) word die belangrikste temas wat later in die brief ontvou en in die slot $(4: 10-20)$ herhaal word, aangekondig (Davis, 1999:153). Die herhaling van die "bid-begrippe" is belangrike struktuurmerkers in die algehele konsentriese struktuur van die brief. Die temas

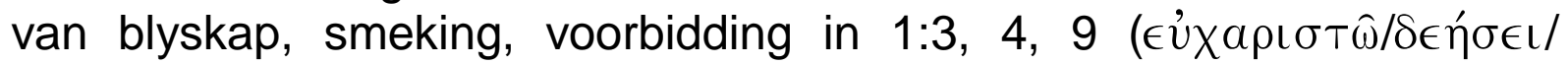

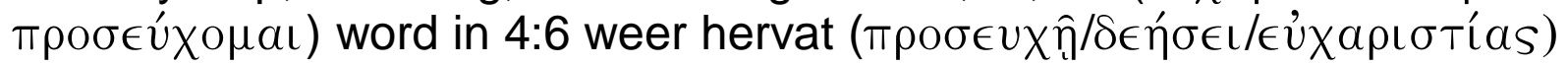
(dus inclusio, vgl. Hayes \& Holladay, 1987:79). So word die lesers wat hierdie trio in die inleiding onthou, herinner dat die einde van die brief naby is (Davis, 1999:155).

Tussen 1:3-26 en 4:10-20 lê twee groot imperatiewe diskoerse wat albei uit $1: 27-30$ volg, naamlik $2: 1-18$ en $3: 1-4: 9$. Verse $1: 27-30$ is die belangrikste retoriese aandrang ("rhetorical proposition") in die brief en handel hoofsaaklik oor "'n lewe waardig aan die evangelie" en oor "eenwees" (1:27). In 2:1-18 (2:1-4; 2:5-11; 2:12-18) en 3:1-4:9 (3:1; 3:2-4:3; 4:4-9) word hierop uitgebrei. Die vertelling oor Timoteus en Epafroditus se bediening (2:19-30) is die sentrale eenheid in die konsentriese struktuur van hierdie diskoerse (Davis, 1999:154). Dit is opvallend dat "waardige gedrag volgens die evangelie" (1:27), met Timoteus en Epafroditus as voorbeelde hiervan (vgl. 2:20, 25, 29), opgevolg deur Paulus se eie lewensvoorbeeld (vgl. 3:8-10) weereens die tema van gemeenskap aan die evangelie benadruk. 


\subsection{Black}

Met verwysing na Kennedy (vgl. Van Deventer, 1999:454, 455) probeer Black (1995:22) die "flow of thought" (vgl. Reed, 1999:30) van Filippense bepaal deur die brief se onderskeie teks-eenhede ("text sequences") en die logiese verbindings tussen hulle te bepaal. Na aanleiding van die Hellenistiese briefvorm identifiseer hy 'n aanhef (1:1-2); liggaam (1:3$4: 20)$ en slot (4:21-23). In die briefliggaam identifiseer hy drie breuke:

- tussen 1:11 en 1:12;

- tussen 2:30 en 3:1;

- tussen 4:9 en 4:10.

Soos Davis wys Black ook op die verband tussen 1:3-11 en 4:10-20. Hy tipeer 1:3-11 soos volg: "In text pragmatic terms, 1:3-11 functions to anticipate the major themes of the remainder of the body" (Black, 1995:26). In 1:3-11 identifiseer hy 'n parallelisme tussen 1:3-8 en 1:9-11 (as motivering vir die eerste breuk). 'n Fyner ontleding toon dat 1:3-8 veral handel oor Paulus se dankbaarheid/blydskap oor die Filippense se deelgenootskap aan die evangelie (Black, 1995:27). Verse 9-11 brei die tema van gemeenskap verder uit met 'n gebed om nog meer liefde (Black, 1995:28). In aansluiting by die bespreking oor Wick (2.2), word ook genoem dat Black tò 入oıтóv in 3:1 as oorgangsaanduider tussen twee diskoerse beskou (Black, 1995:40, vgl. ook Osiek, 2000:17) en in 1:27-2:18 'n "quasi-chiastic fashion" raaksien met 1:27-2:18 (waarin die himne voorkom) as die hart van die brief (Black, 1995:44; vgl. Davis se klem op 1:27-30 [2.3]).

\subsection{Swift}

Swift (1984:237-238) gebruik 'n meer grammaties-historiese metode. Hy verskil skerp van Hendriksen (1962:37-38) en ander skrywers wat meen dat Filippense geen definitiewe struktuur het nie (vgl. ook Hawthorne, 1983:xlvii, xlviii). Hy meen dat Paulus uit al sy goeie herinneringe aan die Filippense een saak benadruk, naamlik die deelgenootskap aan die evangelie (1:5). Dit is die sentrale tema wat volgens Swift soos volg verder in die brief uitgebrei word: 1:9-11 ("applied"); 1:12-26 ("exemplified); 1:27-4:9 ("particularized").

\subsection{O'Brien}

O'Brien $(1977: 22,23)$ sien drie redes vir die skryf van die brief wat reeds in 1:3-8 aangekondig en in in 1:9-11 herhaal word: die Filippense het met 'n geldelike gawe aan Paulus gedink terwyl hy in die tronk was (1:3); hulle was deelgenote aan die evangelie (1:5) en God begin en eindig sy 
werk in hulle (1:6). Die eerste twee sake wys op die mens se werk en die derde op God se werk. Die herhaling van die "dag van Christus" $(1: 6,10)$ wys dat die parousia onderliggend is aan Paulus se gedagtes (vgl. ook $3: 11-14,35)$ en beklemtoon sowel God (1:6) as die mense se werk (1:10) (O'Brien, 1977:28). Die inleiding (1:3-11) "introduces the mood and style of what is to come" en die positiewe sake van die briefliggaam is eintlik reeds in 1:11 opgesom as "vrugte van geregtigheid" (O'Brien, 1977:37).

\subsection{Peterlin}

Peterlin (1995) se bydrae is hier belangrik vanweë die agtergrond wat hy verskaf. Hy meen dat konflik en onenigheid in die gemeente die agtergrond is waarteen die hele brief gelees moet word en selfs die enkele tema is wat die verskillende diskoerse saambind (vgl. Peterlin, 1995:217218 en 1994:207-210 vir 'n oorsig). Tog meen Peterlin dat hy nie Swift se tema (deelgenootskap aan die evangelie) hiermee uitsluit nie, maar eerder komplementeer (Peterlin, 1995:228).

\subsection{Beredenering van navorsing en terrein vir verdere ondersoek}

- Binne die oorwegend Hellenistiese briefvorm is 'n verskeidenheid retoriese tegnieke verteenwoordig: inclusio (Davis, Black); parallelle diskoerse (Wick); konsentriese strukture (Davis), breuke en oorgange (Wick, Black), 'n himne.

- Verskillende resultate wat verskillende ontledingsmetodes opgelewer het (ook buite die retories-kritiese metode om, vgl. Swift, O’Brien), lig

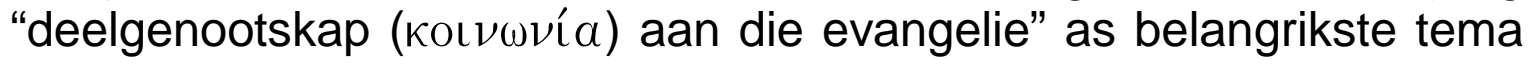
uit.

- Ontleding moet egter geweeg en nie getel word nie. Die direkte aankondiging van "gemeenskap aan die evangelie" as grondoorsaak vir die gebed (1:5); die sterk bewoorde imperatief in 1:27-30, en die himne oor Christus as indikatief kan nie misgelees word nie. Dat die imperatief versterk word deur 'n daadwerklike aksieplan in 2:19-30, wat weer op sy beurt deur 'n beklemtoning van die opdrag (2:1-18; die indikatief) en 'n daaropvolgende uitbreiding en beklemtoning (3:1-4:9) omring word (soos Davis aantoon), maak sin. Die breuk tussen 3:1 a en $3: 1 \mathrm{~b}$ ondersteun die gedagte dat Paulus nogmaals die imperatief in 1:27-30 wil beklemtoon, hierdie keer veral met ' $n$ voorbeeld van sy eie hartsgesindheid teenoor die evangelie en in kontras met die teenstanders (3:2-21). Die parallelle pare wat Wick indentifiseer, lig die himne ook as indikatief uit en versterk die draaipunt tussen 3:1a en 3:1b. 
- Hoewel blydskapsterminologie sterk na vore kom as struktuurmerkers (sien Wick se pare en Davis se indeling), komplementeer dit juis

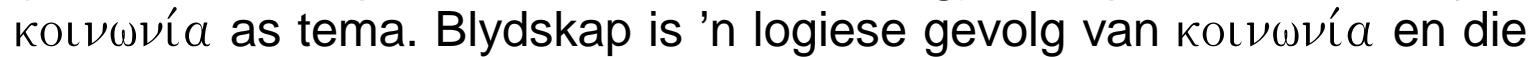
rede vir verdere aansporing - juis binne 'n konteks van konflikhantering (Peterlin)

- Die herhaling van die bid-begrippe (by 1:3, 4, 9) in 4:6 skep 'n onmiskenbare makrostruktuur vir die hele brief (Davis, Black). En dat die belangrikste temas vir die res van die brief in 1:8-11 aangekondig

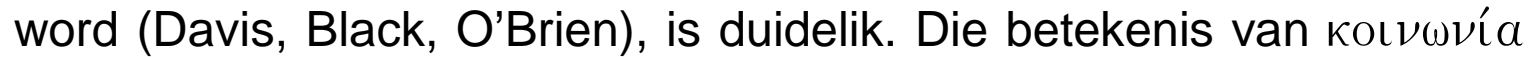
in vers 5 kan egter juis verskraal word deur die verband met die slotopmerking in 4:15 te oordryf. Black (1995:27) sê:

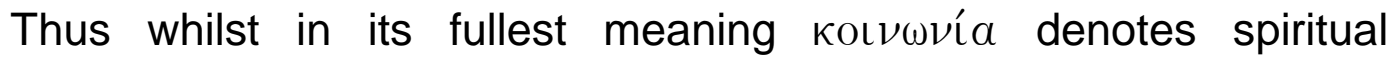
fellowship, its primary reference in 1:5 is to the financial support the Phillipians had given to the apostle. In other words the apostle sees his relationship with the Philippians as one of contractual reciprocity in their common goal of spreading the gospel (Black, 1995:27, ons kursivering, JP, BJdK).

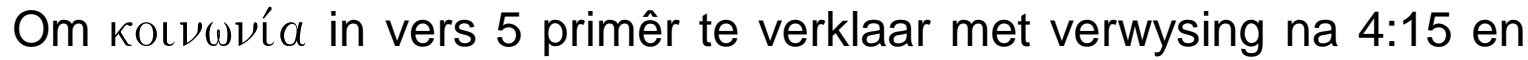
nie in die eerste plek met verwysing na die verse wat vers 5 omring nie, kan die retoriese krag van die ethos, pathos, en veral die performatiewe dimensie (vgl. Du Toit, 1992:473) van die inleiding verswak. Die gesindheid "agter" die tema van gemeenskap aan die evangelie (en die finansiële bydrae) word in 1:3-8 en veral in 9-11 duidelik aangekondig. Hierdie gesindheid is liefde. Trouens, Paulus se gesindheid van pastorale liefde bereik in Filippense 'n diepte wat volgens O'Brien (1977:29, 31, 40) nêrens in die Pauliniese korpus geëwenaar word nie (vgl. 1:8). O'Brien waarsku juis teen die ver-

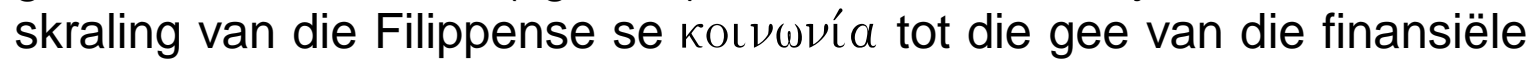
gawe en teen die verskraling van $\epsilon \dot{v} a \gamma \gamma \hat{\epsilon} \lambda \iota \mathrm{\nu}$ soos by Gnilka (O'Brien, 1977:25). Wie die ware spiritualiteit van die brief wil verdiskonteer, moet dus die impak van die oorvloedige liefde in die res van die brief ondersoek.

\section{Die impak van Christus se oorvloedige liefde in Filippense $1: 3-8$ en $1: 9-11$}

\section{1 Inleidend}

Vir die ondersoek na die impak van Paulus se oorvloedige liefde word 1:8-11 en veral 1:9-11 nou op mikrovlak te ontleed. Kernbegrippe word veral met verwysing na Louw en Nida (1989) bespreek. Detailvergelykings tussen semantiese domeine word nie gedoen nie, aangesien aangetoon sal word dat Paulus sy eie semantiese pare kies. Meer 
etimologiese verklarings word ook gegee in 'n poging om die gepastheid (vgl. al $\sigma \theta \eta \sigma \mathrm{s}$ s hieronder) en koloriet (Pretorius, 1995:563) van die begrippe uit te lig.

\subsection{Die retoriese effek van kohesie in en tussen diskoerse 1:3-8 en 1:9-11}

\subsubsection{Herhaling van die "dink-en-bid"-begrippe en die uitbreidings op

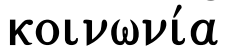

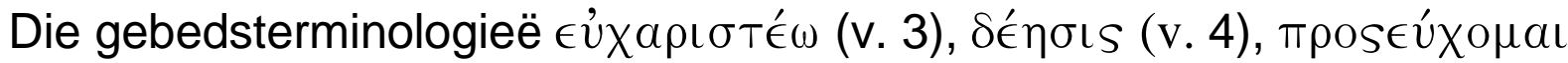
(v. 9) is nie ondergeskik aan mekaar nie, maar lei afsonderlike sinne in, wat semantiese ooreenkomste toon (parataksis [vgl. Reed, 1999:33]). In vers 3 is sprake van danksegging en in vers 4 van voorbidding. Die inhoud van die voorbidding (v. 4) word "teruggehou" (tot vers 9), ten einde eers op die gronde vir die danksegging (v. 3) uit te brei. Vers 5 gee dan die hoofrede vir die danksegging, naamlik "gemeenskap aan die evangelie". Aangesien die geldelike bystand waarskynlik vooropstaan in Paulus se gedagtes (O'Brien, 1977:25; vgl. ook 4:15), word "gemeenskap" in vers 5 veral "horisontaal" (mens tot mens/Paulus en die Filippense) bedoel. In vers 6 word hierdie gemeenskap onmiddellik uitgebrei ("enhancement-reason"; vgl. Reed, 1999:35) met 'n vertikale dimensie (mens tot God). Paulus gaan dus in vers 6 op kleiner skaal te werk op dieselfde wyse as wat hy met die himne op makrovlak doen. Ook die gebedsterminologie in vers 4 het veral 'n vertikale dimensie. So is vers 5 omraam deur twee vertikale dimensies. Met die verwysing na horisontale en vertikale dimensies word die twee hoofdimensies of rigtings van gereformeerde spiritualiteit bedoel (kyk hieroor Oostenbrink \& Lotter, 1999:372, 377-378 - veral 3.2.1, 3.2.10 en 4).

Hierdie patroon van horisontale en vertikale dimensies word herhaal.

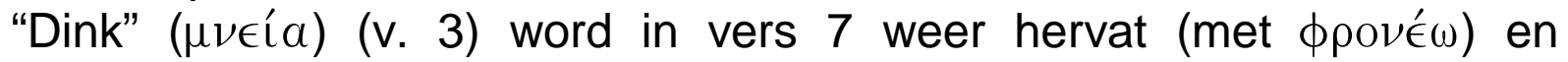
uitgebrei ("enhancement-comparative-positive"; vgl. Reed, 1999:35) met intieme "gemeenskapsterminologie" ("in my hart dra") (Bybel, 1957) en soos in vers 5 begrond met "gemeenskap aan die evangelie".

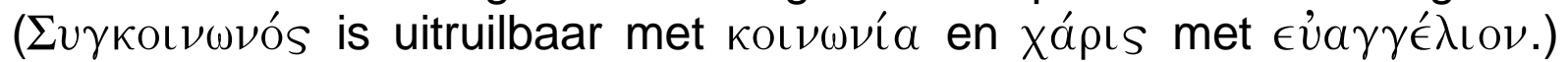
Weer dui die konteks op 'n horisontale dimensie in vers 7 (praktiese hulp van die Filippense aan 'n gevangene). Ook word die horisontale dimensie onmiddellik daarna (v. 8) weer vertikaal uitgebrei. God word as getuie geroep (mens tot God) en die uitbreiding met intieme gemeenskapsterminologie vind ook in hierdie dimensie plaas (vgl. $\sigma \pi \lambda a ́ \gamma \chi \nu$ ov 3.3.2; dus, Christus/God tot mens). Weer is die tema van gemeenskap (v. 7) weerskante omring deur twee vertikale dimensies. Dit plaas vers 6 in die middel, en verleen besondere klem daaraan (indikatief vir die hele brief, uitgebrei deur die himne?). Dus: 


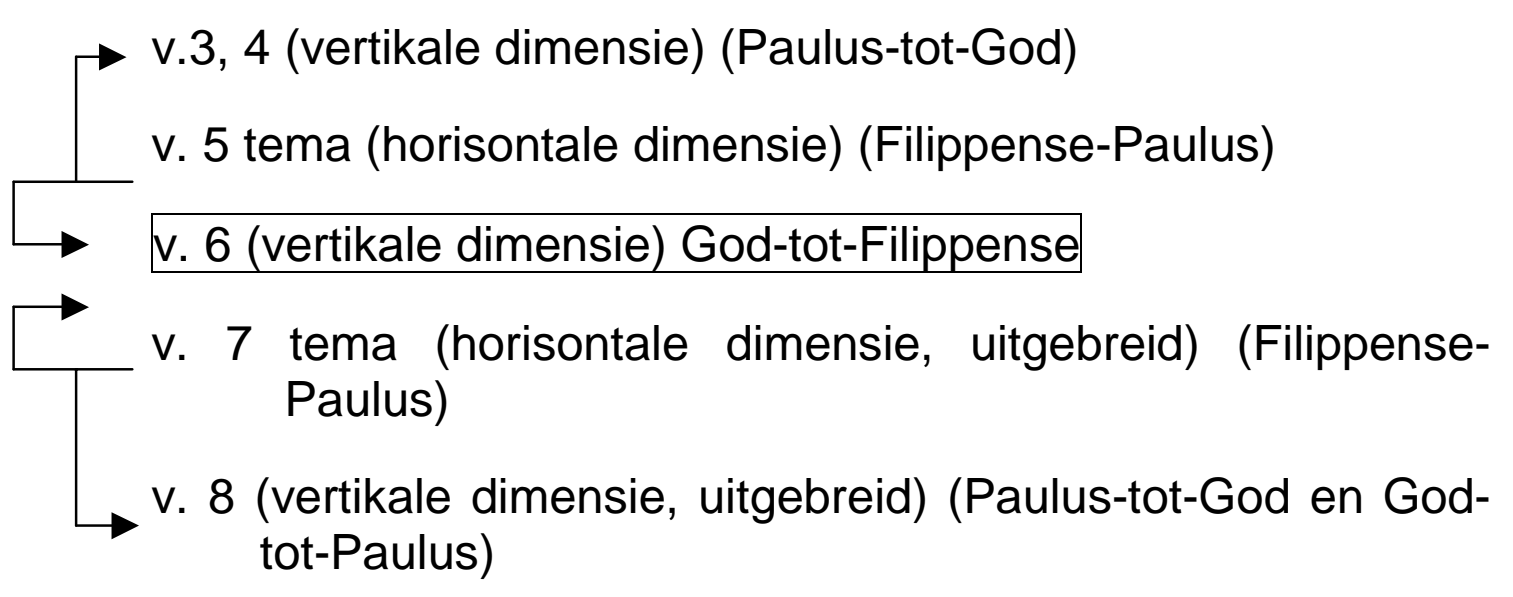

Wat ten opsigte van die gemeente van Filippi se vertikale dimensie nog kortkom, is die dimensie Filippense tot God. Hiertoe kan Paulus hulle nie dwing nie, maar hy bid vir hulle.

\subsubsection{Intimiteit word versterk deur inklusiwiteit}

Die innige gemeenskap met die Filippense word verder versterk met die begrippe "altyd", "almal", "alle" wat deurlopend in die 1:3-11 gebruik word. Hawthorne (1983:17) wys op die kragtige retoriese effek van máọ

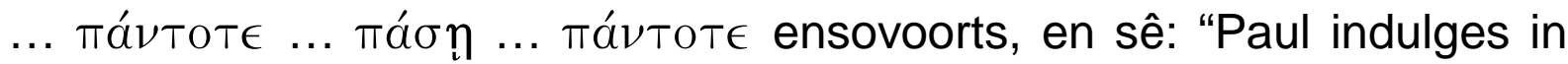
alliteration" omrede hy goed gebruik wil maak van die "rhetorical elegances" van sy tyd (vgl. Black, 1995:29). Hierdie begrippe weef dus die hele perikoop en die partye wat daarin rolspelers is, aanmekaar.

\subsection{Vers 3-8 meer op mikrovlak}

\subsubsection{Reeds innige gemeenskap in vers 3-4}

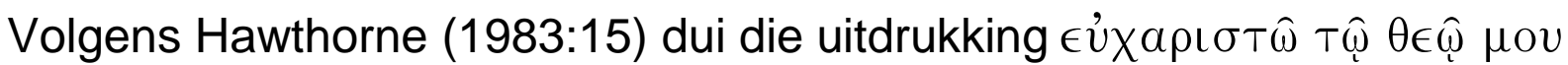
(v. 3) op 'n besondere intimiteit tussen Paulus en God. Paulus staan alleen voor God in gebed, "he keenly senses a close personal and vital relationship with and dependence upon God-'my God' (Hawthorne, 1983:15). Müller (1991:39) sien in hierdie uitdrukking Paulus se "most personal and close alliance of faith with God" (vgl. O'Brien, 1977:29). Vers 3 handel oor danksegging en vers 4 oor voorbidding. Die mooi herinneringe wat Paulus aan die Filippense het (kyk Löh \& Nida, 1979:10 t.o.v. $\dot{v} \mu(\hat{\omega} \nu)$ vul hom in die gevangenis met dankbaarheid teenoor God (v. 3) en met blydskap (v. 4).

\subsubsection{Gemeenskap in vers 6-8}

Hier word volstaan met enkele opmerkings oor vers 6-8:

Vers 6: God het die goeie werk van die evangelie in ( $(\hat{\epsilon} \nu)$ die Fillipense

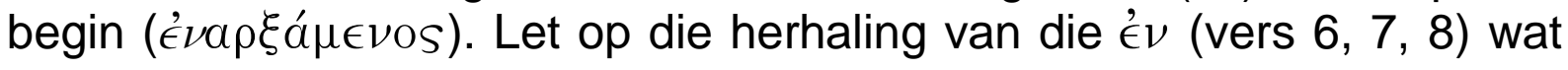


volgens Vine (1981) in vers 6 in letterlike (eksistensiële) sin vertolk kan word. Volgens Louw en Nida (1989:68.3) beteken évápXoual "to begin in a particular state or relationship" (ons kursivering - JP, BJdK). O'Brien

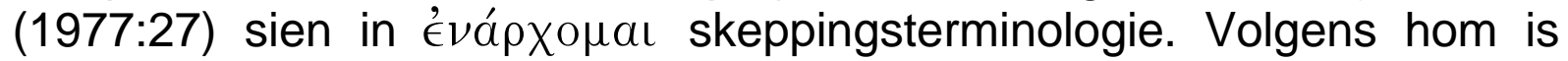
verlede, hede en toekoms ter sprake (Hawthorne, 1983:20-21). Die verwysing na die wederkoms word in vers 10 herhaal.

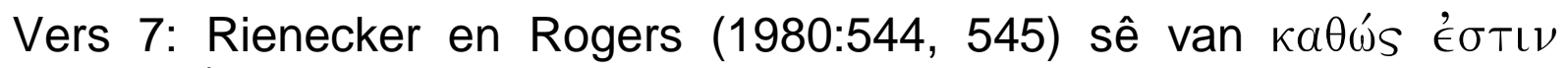

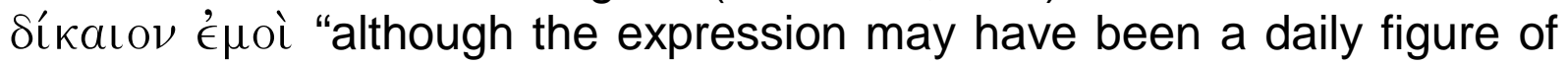
speech (Lohmeyer) the word does contain an ethical (vgl. '́t $\pi i \gamma \nu \omega \sigma \iota s$ by 3.4.2.2) and general moral sense which has its foundation in the moral relation of man to God" (ons kursivisering - JP, BJdK). Black (1995:29)

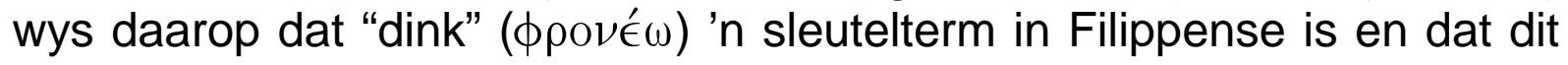
in vers 7 die eerste van tien kere is dat Paulus die woord gebruik. $\Phi \rho \nu^{\prime} \in$ is ook in 2:5 die "brug" na Paulus se beskywing van die gesindheid van Christus wat in die himne besing word (vgl. $\sigma \pi \lambda a ́ \gamma \chi \nu$ oıs X

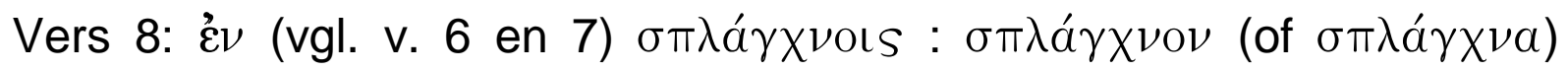
(v. 8) beteken ook "ingewande", en dui op die intiemste emosies. Louw en Nida (1989) gee die volgende betekenisvelde: "intestines (8.58); desires (26.11); compassion (25.49); object of affection (25.50)." Opgesom in die woorde van Wuest (1997):

What a miracle of divine grace for this heretofore proud Pharisee to have tender heart-longings for these former pagan Greeks! But that is not all. He tells them that this longing is in the bowels of Jesus Christ. The inner organs, here designated by the word 'bowels', were regarded by the ancients as the seat of the tender affections. The word used here refers to the upper organs, the stomach, liver, and lungs, another word being used for the intestines. We would say 'the heart'. Paul thus describes his longing, not as his individual emotion, but as Christ's longing, as if the very heart of Christ dwelt in Paul. The great apostle lived so close to the Lord Jesus, and he had so shared the sufferings of his Lord for righteousness' sake, that his heart was very tender, and beat as one with the heart of Jesus (vgl. Homer, 1984:107)

\subsubsection{Samevatting: vers 3-8}

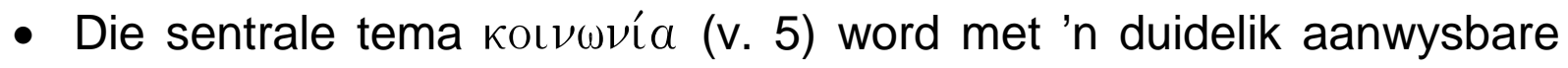
retoriese struktuur met horisontale en vertikale dimensies begrond.

- Daar is werklike, eksistensiële gemeenskap tussen Paulus en die Filippense, die Filippense en Paulus, maar ook tussen Paulus en God/Christus, en God-tot-die Filippense. 
- Die begrippe wat in 1:3-8 gebruik word, onderstreep die impak van Christus se liefdesgemeenskap met Paulus.

- Die vertikale dimensie van die Filippense-tot-God-gedagte word grootliks oopgelaat en open sodoende die deur vir Paulus se gebed.

- Vers 1:3-8 toon progressiewe opbou na die gebed in 1:9-11.

\subsection{Eksistensiële gemeenskap lei tot 'n gebed om nog meer oorvloedige liefde (1:9-11)}

Hierbo is reeds aangetoon dat 1:9-11 'n uitbreiding is op die voorbidding waarna in vers 4 verwys word (Swift, 1984:240). Verse 1:9-11 word nou ontleed deur enkele opmerkings oor die sintaksis van die perikoop, die aantoon van sekere kernbegrippe en 'n hipotese dat hierdie begrippe in pare gerangskik kan word.

\subsubsection{Sintaksis van 1:9-11}

$\Pi \rho o \sigma \epsilon u ́ x о \mu a l$ is die hoofwerkwoord waaraan die res van die perikoop sintakties verbind is. Die toename in liefde is die hoofobjek van Paulus se gebed í $\nu \alpha$ + subjunktief stel 'n gesubstantiveerde sin, in hierdie geval epeksegeties, by die voorafgaande Tov̂тo. 'Ev dui die opsig aan waarin

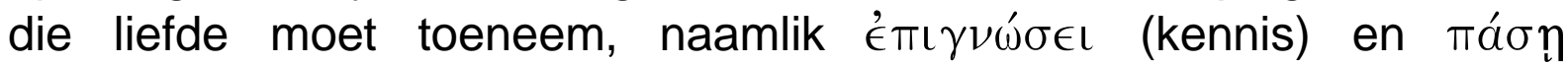
ai $\sigma \theta \eta \dot{\sigma} \sigma \iota$ (alle ervaring). Die motivering vir die toename in liefde word deur twee doelsinne aangedui, naamlik:

- die onderskeiding/toetsing tussen belangrike en minder belangrike sake en

- hoe die gelowige sal/moet wees op die dag van Christus. Hoe die gelowige sal/moet wees op die dag van Christus, word soos volg gekwalifiseer: so 'n persoon is opreg, sonder blaam/is nie 'n struikelblok nie en is vervul met die vrug van geregtigheid van Christus self.

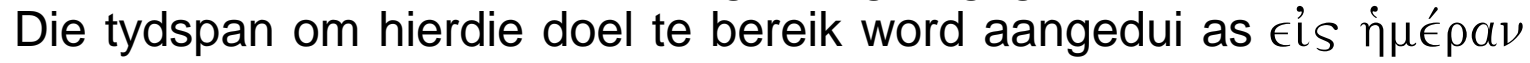
X

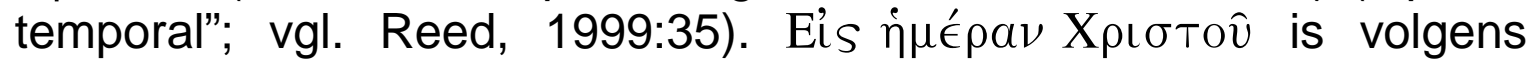
O'Brien meer as net tydspan. "It is better to translate it 'in view of' or 'against' the day of Christ. Nie net die bereiking van die dag nie, maar die doel van die dag (die verheerliking van God) is in die oog (by 2.6) (O'Brien, 1977:35). Die einddoel van die gebedsverhoring is die "heerlikheid en die lof van God" (vgl. v. 6). 


\subsubsection{Enkele kernbegrippe in 1:9-11}

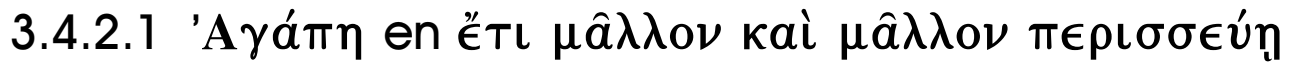

Uiteindelik gee Paulus die sentrale inhoud van sy voorbidding (v. 4),

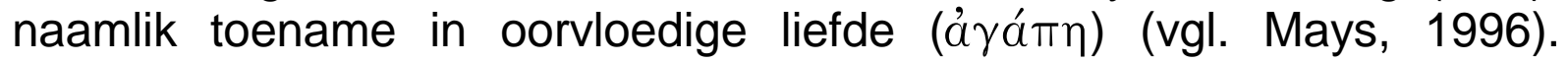

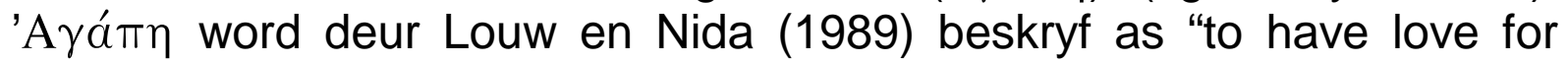
someone or something, based on sincere appreciation and high regard to love, to regard with affection, loving concern, love". In die Bybel word

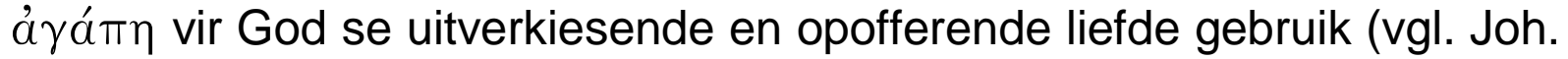
3:16). Dit is ook hierdie liefde wat Hy van sy kinders vir Hom en vir mekaar vra (vgl. Pop, 1957:137-141). "Agape is decision love. Agape is the decision to make sacrifice. It is the decision to make deep personal sacrifice for the sake of the beloved" (Hansen, 1998a:104). Liefde het dus 'n "horisontale" en "vertikale" dimensie wat keuses vra om jouself op te offer (vgl. Mark. 12:28-31 en die bespreking hierbo by 3.2.1). Verder is

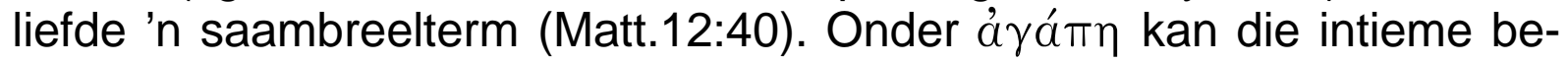
grippe van vers 7 en 8 tuisgebring word, asook praktiese hulpverlening. Liefde beskryf Paulus se hele gesindheid en optrede en is die sentrale inhoud en doel van sy gebed en hele bediening aan die Filippense (Houlden, 1977:53). Paulus is egter onmagtig om aan die Filippense dieselfde gesindheid te gee, alhoewel hy hulle dade kan beoordeel. Hy oordeel dat hulle reeds oorvloedige liefde besit (Braune, 1980:15; O'Brien, 1977:31), maar dit kan en moet nóg meer oorvloedig word. Alhoewel hy onmagtig is om hulle liefde te laat toeneem, kan hy hiervoor bid terwyl hy op God vertrou (v. 6). Hy kan liefde ook demonstreer deur sy eie lewe (vgl. 3:2) en deur sy advies.

The love spoken of here is the love that God is (I John 4:16), produced in the heart of the yielded believer by the Holy Spirit (Rom. $5: 5)$, its chief ingredient, self-sacrifice for the benefit of the one who is loved (John 3:16), and its constituent elements analyzed for us in I Corinthians 13 (Wuest, 1997).

Die ware liefde van Christus mag nie en kan nie staties wees nie (vgl. 3:12). Dit moet altyd meer en meer toeneem in die "kennis" ('́Tí $\gamma \nu \omega \sigma \iota s)$ van Christus en "alle ervaring" (al゙ $\sigma \eta \eta \iota s)$.

\subsubsection{2 'Emí $\gamma \nu \omega \sigma \iota s$ en aï $\sigma \theta \eta \sigma \iota s$}

'Eாí $\gamma \nu \omega \sigma \iota s$ en dî́ $\theta \eta \sigma \iota s$ brei die konsep liefde uit ("enhancement-

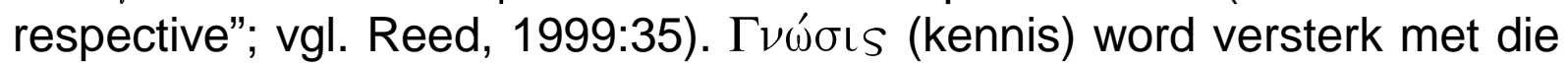
intensiewe voorsetsel ('́Tा). 'E $\pi i ́ \gamma \nu \omega \sigma \iota s$ dui dus op 'n dieper en meer gevorderde kennis, diepgang of bedrewenheid (Breed \& Jordaan, 2000: 213) - vandaar Wuest (1997) se vertaling "volle kennis". Volgens Wuest (1997) veronderstel $\epsilon$ 'í $\gamma \nu \omega \sigma$ ss kennis wat deur ervaring opgedoen word 
en nie intuïtiewe kennis nie. Die objek van hierdie kennis is God se wil en om Jesus persoonlik en intiem te ken. God het die goeie werk in ('́ $\nu$ ) die Filippense begin (1:6), en sal in hulle bly werk (2:13). Van hulle kant moet hulle nou meer oorvloedig word in hulle liefde en kennis van Hom en die gepaardgaande fyn aanvoeling ( $\alpha$ l $\sigma \theta \eta \sigma \iota s$ ) van hulle dade (vgl. 1:8; Kol. 1:9 en Müller, 1991:45). Liefde sonder kennis het geen inhoud nie, en kennis sonder liefde kom tot niks nie (1 Kor. 13:2). Meer nog, die kennis "maak opgeblase, maar liefde bou op" (1 Kor. 8:1; vgl. Hendriksen, 1988:60). Paulus begin onmiddellik in 1:12 om die kennis van die Filippense op te bou deur hulle te wys op wat God reeds in hom gedoen het: "ek wil hê julle moet weet $(\gamma \iota \nu(\omega) \sigma \kappa \omega)$ broers wat ek wedervaar het

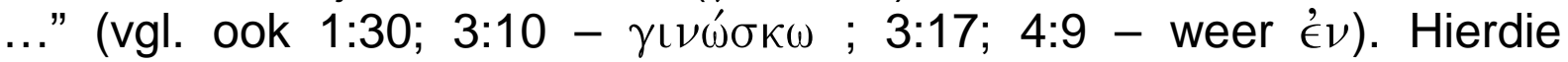
voorbeelde uit Paulus se eie lewe getuig van die ken van Jesus wat in gepaste dade oorgegaan het (vgl. al $\sigma \theta \eta \sigma \mathrm{s}$ in die volgende paragraaf).

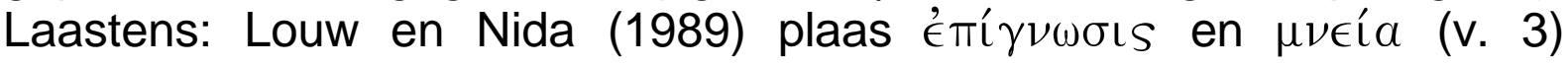
onderskeidelik in semantiese domeine 28 ("know") en 29 ("recall from

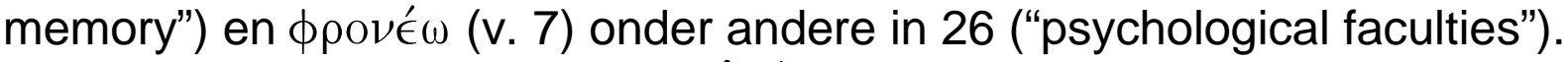
Vir 'n vollediger bespreking van é $\pi i ́ \gamma \nu \omega \sigma \iota s$ vergelyk Breed en Jordaan (2000:213-214).

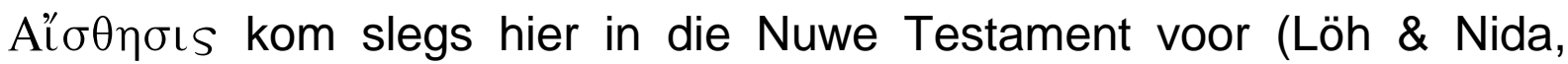
1979:16). Die Afrikaanse (en Engelse) woord "esteties") is van hierdie woord afgelei. Funk en Wagnalls (1980:263) beskryf 'n "esthete" as "one who is very responsive to beauty in art, nature etc.; one who effects or seeks sensitivety". Louw en Nida (1989) dui die semantiese velde van die Griekse woord aan as die vermoë om te verstaan en die vermoë om sake te kan beoordeel/te kan onderskei (32.28). Die woord het dus te make met persepsie, oordeelsvermoë en ook takt (Homer, 1984:109). Wuest (1997) beskryf die term as "sensitive moral perception, and a quickness of ethical tact". Lenski (1961:171) bring dit in verband met praktiese lewenservaring (vgl. $\left.\epsilon^{\prime} \operatorname{í}_{\gamma} \nu \omega \sigma \mathrm{s}\right)$ ). Daarom is dit ook heel gepas dat al $\sigma \theta \eta \sigma \iota s$ hier gevolg word deur twee begrippe wat handel oor

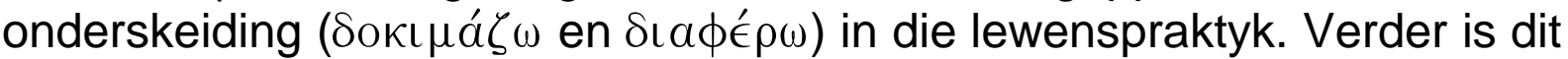
belangrik dat Paulus bid vir 'n toename in "alle" estetika van die liefde (vgl. 3.2.2). Daar is dus geen terrein waarop die fyn aanvoeling van die liefde nie na vore moet kom nie. Die voorbeelde wat Paulus uit sy eie lewe meld, getuig van hierdie fyn aanvoeling.

\subsubsection{3 $\Delta о \kappa \iota \mu a ́ \zeta \omega$ en $\delta \iota a \phi \epsilon ́ \rho \omega$}

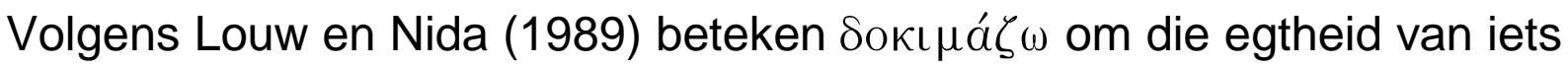
vas te stel deur toetsing (27.45), om te bevind dat iets gepas of die moeite werd is (30.98); om iets as eg te beskou, omdat dit getoets is (30.114). Volgens Wuest (1997) is die woord gebruik vir die finale onder- 
vraging van 'n mediese student wat reeds al sy eksamens geslaag het. Die verwagting van die uitslag is dus positief (dat die student sal slaag).

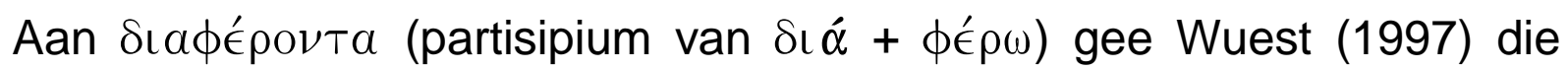
volgende uitleg:

The expression 'the things that are more excellent' ... comes from a word that means 'to carry two ways', (vgl. Louw \& Nida, 1989 ... thus 'to carry different ways', [15.163] and ... 'thus to differ' [25.41]). It refers here to those moral and spiritual concepts and actions which involve delicate and keen distinctions, those that require a deep and keen discernment to recognize. Not the ordinary, every-day, easilyunderstood spiritual obligations, but the finer points of Christian conduct are in the apostle's mind (vgl. Louw \& Nida, 1989:65.6).

Die woord is ook gebruik vir die suiweringsproses van metale (Robertson, 1998) - vgl. die Eng: "ex-ellent" en Afr: "uit-staande").

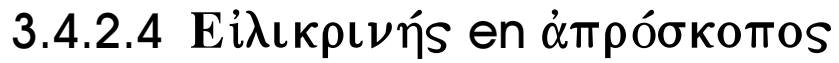

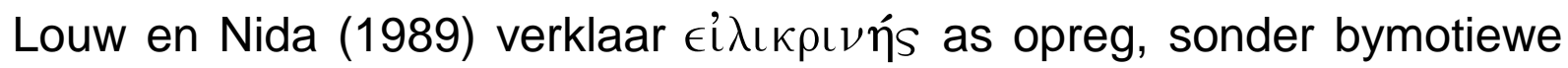
(88.41). Ei $\lambda \iota \kappa \rho \iota \nu$ ́s is 'n baie ou woord en is waarskynlik saamgestel uit

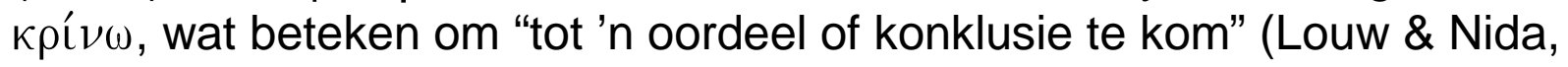
1989:30.75) en $\in \hat{\imath} \lambda \eta$ (die hitte of strale van die son). Hierdie woord hou verband met die konnotasie van getoets deur skerp sonlig, of om deur 'n uitrolproses te gaan, rein te wees (Robertson, 1998). Dit word ook gebruik om die suiweringsproses van metale totdat 'n onvermengde

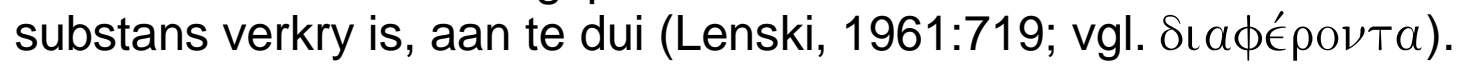

'Aтрóбкотоs beteken volgens Louw en Nida (1989), vry van kritiek of beskuldiging (88.318), of dit wat nie aanstoot gee nie (25.184).

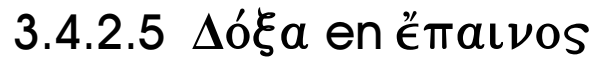

Die eerste begrip is meer algemeen, maar die tweede het te make met 'n uiterlike respons op die heerlikheid van God - "praise (" ascribed to God, in respect of His glory, the exhibition of His character and operations" (Vine, 1981). Die wederkoms is in die oog (vgl. v. 6).

\subsubsection{Opsomming en interpretasie van semantiese pare}

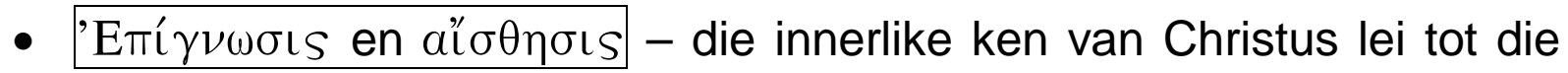
sigbare skoonheid van die liefde in elke situasie.

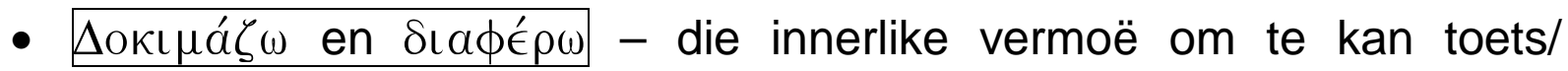
onderskei, bring die beste/dit wat uitstaande is, aan die lig. 


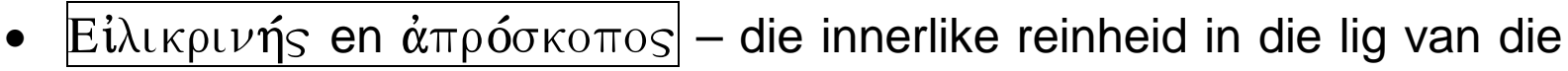
oordeel voor Christus, sal elke moontlikheid van blaam deur iemand anders negativeer.

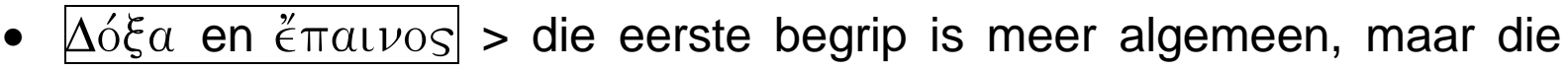
tweede het te make met 'n uiterlike respons op die heerlikheid van God.

\subsubsection{Samevatting van 1:9-11 in samehang met 1:3-8}

Vers 1:9-11 toon 'n verweefdheid met en uitbouing van die gedagtes van 1:3-8. Die sentrale tema of hoofgedagte van "gemeenskap aan die evangelie" kan alleen vertikaal begrond word deur God self. Vir die impak daarvan kan gebid word. Die spesifieke gebedsinhoud is die liefde. Liefde is 'n omvattende term wat alle ware horisontale en vertikale gemeenskap moontlik maak. Wanneer hierdie liefde beleef word, en dit meer oorvloedig word in 'n werklike ken van Christus, lei dit tot fyn aanvoeling in die optrede van die gelowige, tot 'n onderskeiding van dit wat vir God uitstaande is as werklike vrugte van Christus se kruisdood, en dit wat Hom verheerlik.

Paulus het die impak van Christus se oorvloedige liefde in sy hart beleef (v. 5, 7, 8) en bid nou ook daarvoor vir die Filippense (v. 9). Die dryfkrag van Paulus se liefde is die eksistensiële liefde van Christus wat besig is om deur Paulus te werk (vgl. 2:13) en hy groei self nog verder daarin (3:14).

\section{Die verband tussen die gebed om oorvloediger liefde en die hantering van konflik in die res van die brief}

Die unieke struktuur van die brief is nie net sigbaar in die retoriese samestelling nie, maar kan veral gesien word in die advies wat Paulus gee.

\subsection{Konflik binne en buite die gemeente}

Die gedagte van konflik binne en buite die gemeente (o.a vervolging, vgl. Telbe, 1994:106) kom in die Filippensebrief voor. Peterlin (1995) identifiseer konflik en onenigheid selfs as die hoofoorsaak van die brief. Hy gebruik dan ook die identifisering van konflikareas vir 'n indeling van die brief (Peterlin, 1995:v-vii). Daar is ook 'n verskeidenheid teenstanders wat deur Peterlin (1995:135-169) bespreek word. Omdat die teks nie self spesifiek sê wie hulle is nie, is dit moeilik om hulle nader te tipeer (Bateman, 1998:61). Bateman (1998:51) identifiseer die teenstanders van Paulus en of die Filippense in die volgende gedeeltes: 1:15-17; 1:27- 
28; 3:2-3; 3:18-21. Ander gevalle van konflik word ook gemeld te wete: diegene wat nie eensgesind is nie (2:2), hulle wat in selfsug en selfverheerliking optree (2:3), wat murmureer (2:3) en Euodia en Sintige (4:2) (vgl. Peterlin, 1995:27).

\subsection{Verband tussen die hantering van die konflik en die gebed in 1:9-11}

Met Peterlin (1995:6-8, 227) word saamgestem dat Filippense nie net 'n brief is wat veral vriendskaplike en 'n aantal ander temas hanteer nie (vgl. Alexander, 1989:99; Hawthorne, 1983:xlvii, xlviii), maar dat die brief geskryf is om bestaande konflik in die gemeente op te los. Waar die gebed vra vir meer oorvloedige liefde, is die afwesigheid van hierdie oorvloedige liefde (wat getuig van kennis en die estetiese) die aanleiding tot die skrywe. Die verband tussen die liefdestema en die konflik in die res van die brief blyk uit die volgende:

Die tema van liefde word woordeliks in die res van die brief herhaal.

- In 1:17 tref Paulus 'n vergelyking tussen mense wat Christus verkondig met valse motiewe ("naywer"). Hierteenoor is daar ander wat Christus verkondig uit liefde vir Paulus en ook uit liefde vir Paulus se saak (die verkondiging van die evangelie) (vgl. Ferguson, 1997:2223).

- Hoofstuk 2:1, 2 wat liefde as 'n konflikhanteringsmeganisme benadruk, word soos in 1:3-11 baie sterk aan die gemeenskap van gelowiges gekoppel.

Ewe belangrik (as die woordelikse verband tussen die liefde as tema

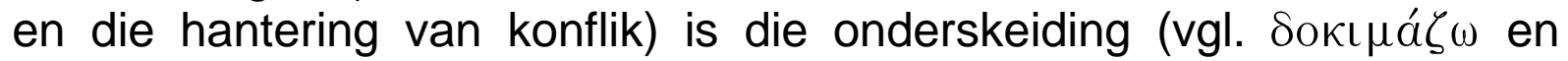
$\delta \iota a \phi \epsilon ́(\omega)$ wat Paulus self oor die hantering van konflik maak. Hy onderskei duidelik tussen verskeie teenstanders en hanteer hulle verskillend (vgl. Wuest se definisie van al $\sigma \theta \eta \sigma ı s ~ 3.4 .2 .2)$.

Die gebed kan van toepassing gemaak word op elkeen van die konfliksituasies. Hier word volstaan met 'n bespreking van 1:15-25 en enkele opmerkings oor die res van die brief.

\subsection{Gebed as konflikhanteringsmeganisme (1:15-25).}

Vervolgens word die begrippe wat in die gebed aangetref word, toegepas ten opsigte van die konflik met mense wat Paulus se gevangenskap swaarder wou maak. 


\subsubsection{Die konflik tussen Paulus en mense in die gemeente}

Dikwels word die naam van 'n gevangene deur die samelewing belaster. Die persoon is immers in die tronk omdat die owerheid meen dat hy/sy die samelewing skade berokken het. Berigte hieroor maak die tronklewe nog swaarder. In 1:17 lees ons hiervan: "Hulle oogmerk is om die gevangenisskap vir my nog swaarder te maak". Wat die teenstanders gedoen het, word duidelik gesê: hulle het die evangelie van Christus verkondig (1:16). Die gedagte dat hulle Judaïstiese dwaalleraars was, moet dus afgewys word (vgl. Müller, 1991:53).

Die beweegredes (en gevolge) van die mense se optrede word in 1:15, 16 soos volg aangedui:

- $\Phi \theta$ óvos ("afguns/jaloesie") wat volgens Louw en Nida (1989) verwys na 'n gesindheid wat in iemand is as gevolg 'n voordeel/voorsprong wat iemand anders het, jaloesie (hier op Paulus se persoon en werk) (88.160).

- 'Epıs (twis/om iets teen iemand te hê) wat volgens Louw en Nida (1989) beskryf word as "conflict resulting from rivalry and discord" (39.22).

- 'Epı $\theta$ eía (selfsug, vyandigheid) wat volgens Louw en Nida (1989) beskryf word as "a feeling of hostility or opposition; a feeling of resentfulness based upon jealousy and implying rivalry - "selfish ambition, rivalry, resentfulness" (39.7).

- Oưx àyvôs (nie met suiwer bedoelinge/motiewe nie - Ferguson, 1997:22).

Al hierdie begrippe dui op 'n afwesigheid van liefde (ten minste vir Paulus).

Wat hierdie mense presies gedoen het, word nie gesê nie. Hoe kon hulle Paulus persoonlik te na kom deur die evangelie te verkondig? Waarskynlik het Paulus se gevangenisskap nou aan hulle die ideale geleentheid gebied om self die evangelie te verkondig, Paulus in die proses subtiel verdag te probeer maak en oorskadu en sodoende sy eer vir hulleself in te oes. Henry (1996) sê:

They were secretly pleased when he was laid up in prison, that they might have the better opportunity to steal away the people's affections; and they laid themselves out the more in preaching, that they might gain to themselves the reputation they envied him (vgl. ook Peterlin, 1995:36-37). 
4.3.2 Paulus se reaksie teenoor sy persoonlike teenstanders en die gebed in 1:9-11

'E $\operatorname{li} \gamma \nu \omega \sigma \iota s$ en aĭ $\sigma \eta \eta \sigma \iota s$

- Paulus weier om die valse motiewe van sy teenstanders tot 'n innerlike konflik te laat groei. Hy sê: "wat maak dit saak"? (1:18). Waarom is sy persoonlike nadeel vir hom bysaak?

- Paulus is nie hier met 'n sielkundige truuk van positiewe denke besig is nie. 1:5 en 6 vorm die agtergrond van sy reaksie: die gemeenskap aan die evangelie is die eerste saak waarvoor hy God dank (1:5). Ook hy identifiseer en vertrou God se werk in mense (1:6). Daarom kan hy hom nou weer eerlik verbly as hy hoor dat Christus verkondig word, al is dit deur mense wat hom wil benadeel. Hy pas hier toe wat hy later in 3:8 sê: "Ja, nog meer: ek beskou alles as waardeloos (hier sy eie reputasie - JP/BJdK), want om Christus Jesus, my Here, te ken ( $\gamma \nu \omega \hat{\sigma} \in \omega s)$, oortref alles in waarde. Ter wille van hom het ek alles prysgegee en beskou ek dit as verwerplik sodat ek Christus as enigste bate kan verkry" (ons kursivisering - JP/BJdK). Kan die fyn aanvoeling van liefde nie juis na vore kom teenoor mense wat jou haat nie? (vgl. Matt. 5:46, 47).

- Die keurigheid van Paulus se liefde is dat hy geen verdere twis as gevolg van jaloesie wil bevorder nie. As mense dan jaloers is op hom, stel hy dit duidelik dat daar geen rede is om jaloers te wees op hom nie, want dit gaan nie oor hom nie, maar oor Christus.

\section{$\Delta 0 \kappa \iota \mu a ́ \zeta \omega$ en $\delta \iota a \phi \epsilon ́ \rho \omega$}

- Paulus het die vermoë om die getuienis van hierdie mense te toets

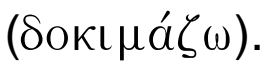

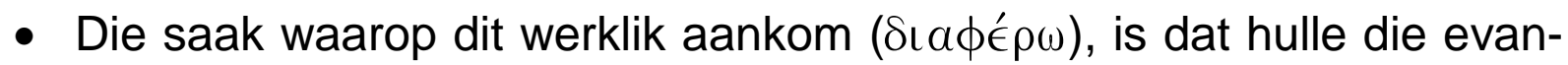
gelie suiwer verkondig.

- Hy onderskei twee groepe mense: dié wat uit liefde vir hom en Christus die evangelie verkondig, en die ander wat sy lyding wil vererger.

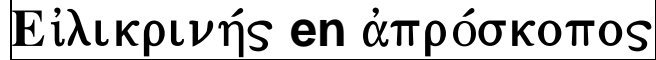

- Paulus se rein hart voor die aangesig van God kom duidelik na vore. Hy begeer niks in eiebelang nie.

- Die teenstanders wat naywerig op Paulus is, sal met die wederkoms van Christus nie kan aanvoer dat Paulus vir hulle 'n struikelblok was nie. Nie oor Paulus nie, maar oor hulle eie sondige motiewe struikel 
hulle. Meer nog: met die oordeelsdag sal aan die lig kom of Paulus se vermaning bekering by die teenstanders veroorsaak het.

- Ander wat uit liefde vir Paulus se saak die evangelie verkondig het, sal soos Paulus sonder blaam voor Christus staan.

\section{$\Delta o ́ \xi a$ en étraıvos}

- Nie sy eer nie, maar dié van Christus staan voorop vir Paulus.

\subsection{Konflikhantering in die res van die brief}

Bogenoemde toepassings sal ook gemaak kan word ten opsigte van ander konflikareas wat in die brief vermeld word. So word die mense wat uit selfsug en ydele eer optree (2:3), asook die murmurerendes en opstandiges (2:14) opgeroep om Christus beter te ken deur dieselfde

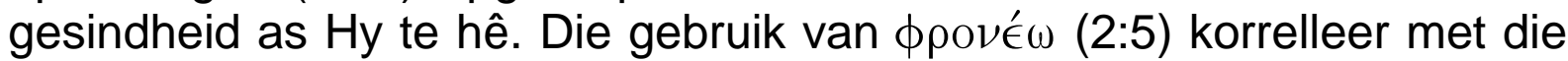

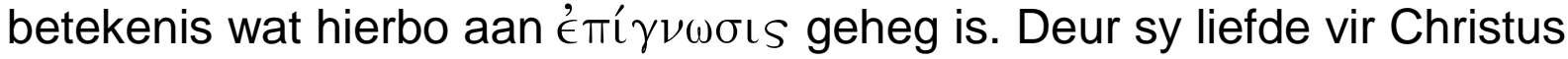
kan Paulus die vyande van Christus duidelik onderskei en uitwys

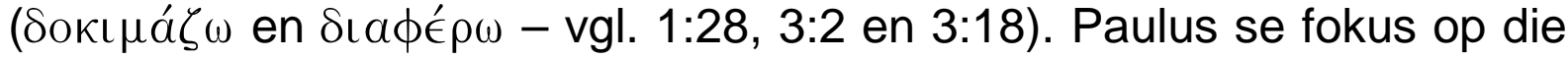
ken van Christus, en die fyn aanvoeling (al $\sigma \theta \eta \sigma \iota s$ ) van sy liefdesdade, is ' $n$ voorbeeld vir die teenstanders (vgl. 1:27 en 3:8-10, 17). In sy beoordeling van Euodia en Sintige vermaan Paulus albei en rig hy sy gedagtes weereens (soos by 1:18) op hulle bydrae ten opsigte van die evangelie. 'n Paar verse verder vra hy die Filippense om hulle gedagtes

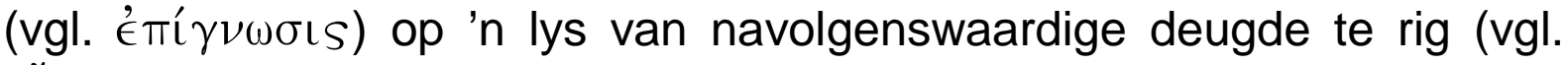
dï $\sigma \theta \eta \sigma \iota s)$.

\section{Die impak van Jesus se liefde as sleutel vir die konflik- hantering}

\subsection{Ooreenkomste: konflik in Filippense en konflik in heden- daagse gemeentebouprosesse}

Vir die term "gemeentebou" word aansluiting gevind by die definisie van Nel wat gemeentebou sien as 'n bediening waarbinne die gemeente opgelei en begelei word om sy eie wese en bestaansdoel te verstaan; sy eie funksionering te evalueer en op voortgaande basis strukture vir funksionering te ontwikkel (Nel, 1994:14). Hierdie strukture moet funksioneel wees vir die "omvattende bouwerk na binne (binne die gemeente as liggaam van Christus) en na buite (die uitdra en die uitleef van die evangelie)" (Du Plooy \& Venter, 1996:353).

In hierdie besluitnemingsproses van gemeentebou kom konflik dikwels voor tussen die leiers en gemeentelede en gemeentelede onderling (Nel, 1994:133; vgl. Burger, 1995:34). Fenton (1997:164) beskryf konflik as 
verskille wat so ernstig word dat besluite nie geneem kan word nie, of dat bestaande besluite nie uitgevoer kan word nie. Leas (1997:45-54) bespreek die tien mees voorspelbare tye van konflik in Amerikaanse makrogemeentes en agt uit die tien handel direk oor gemeentebouscenarios.

In Gereformeerde Kerke (GKSA) behels gemeentebou ook die praktiese "invulstruktuur" (vgl. Du Plooy, 1998:61) binne die beginsels van gereformeerde kerkregering (soos vervat in Kerkordes). Oor die vraag of die "kerklike weg" soos deur die Kerkorde gereël, genoegsame (of te veel?) gereedskap vir konflikhantering in die gemeentebouproses verskaf, moet ernstig en nuut gedink word. Die kasuïstiek van ingewikkelde sinodebesluite word jaarliks aangevul deur beswaarskrifte en appèlle na meerdere vergaderings vanweë onopgeloste konflik in gemeentes oor die praktyk van kerkwees. Of daaropvolgende uitsprake bydra tot die herstel van gebroke verhoudinge kan ernstig bevraagteken word. Dit lyk eerder of die doelmatighede van fyn aanvoeling (Fil. 1:9) en duidelike onderskeiding (Fil. 1:10) plek gemaak het vir konflik en ambivalensie (vgl. Hansen, 1998b:39). Soos die dag van Jesus naderkom (Fil. 1:11), word die oproep vir die praktiese ondersoek na en inkleding van hierdie gebed al hoe dringender. Juis hierdie gebed kan lidmate op gemeentevlak dring om doelbewus nader aan mekaar te beweeg (vgl. Preston, 1997:165).

\subsection{In hoe 'n mate word die impak van Jesus se liefde gesoek?}

'n Vollediger empiriese ondersoek sal na aanleiding van bostaande resultate gedoen kan word. Hier word volstaan met enkele voorbeeldvrae (bv. op 'n skaal van 1-10) waarmee gepoog word om vas te stel in hoe 'n mate konflik met die liefde van Jesus gehanteer word.

- Word vennootskappe ("partnership") vir die bevordering van die evangelie gesoek en gewaardeer (vgl. 2.6; 3.1; 4.3.2) of in die lig van moontlike verskille vermy? (vgl. 3.2.2).

- Om die liefde van Christus in 'n besondere konfliksituasie te evalueer, kan die volgende vrae gevra word:

- Bid die betrokkenis tydens die hantering van die konflik? (vgl. 3.2.1; 3.3.1);

- Begin die gebed eerlik by die positiewe of by die negatiewe aspekte van die verhouding tussen die partye? Anders gestel: begin elkeen deur die werk van Jesus in die harte van hulle opponente te oordink en God eerlik daarvoor te dank? (vgl. 1:6; 3.2.1; 3.3.2 t.o.v. v. 7); 
- Verwag en vertrou betrokkenes dat God goeie werk in die harte van mede-Christene sal doen? (3.2.1, sien skematiese voorstelling; 3.3.2 ten opsigte van v. 6).

- In die evaluering van die mate waarin die betrokkenes instrumente is vir die effek wat Christus se liefde kan hê in opponerende medeChristene se harte, kan die volgende vrae aan die orde kom:

- Bid hulle eerlik en ernstig vir meer en meer ware Christusliefde in hulle harte? (vgl. 3.4.2.1)

- Monitor die betrokkenes die gevolge van hulle gebede ten opsigte van:

○ hulle groter intimiteit met Christus en ander Christene (3.4.2.1);

- hulle kennis wat in skone dade na vore kom (3.4.2.2);

o duideliker onderskeiding van wat werklik belangrik is (3.4.2.3);

○ ewigheidsperspektief oor die vrugte van geregtigheid voor God (3.4.2.4; 3.4.2.5).

\section{Samevattende opmerkings}

Tereg het Berkhof (aangehaal deur Du Plooy, 1991:77) opgemerk: "Geen denken over God is ter zake, dat niet opkomt uit een ontmoeting met God" en "... geen denken over God is ter zake, dat niet gericht is op de ontmoeting met God". Die impak van die liefde tussen Paulus en Christus kom op 'n treffende wyse deur die diskoerse in hierdie brief na vore. Paulus het Christus lief en ken $\operatorname{Hom}(3: 8,10)$. Christus het Paulus lief, ken hom, het hom gegryp (3:12) en werk sigbaar in hom (1:30, 4:9). Christus wil egter nie net in en deur Paulus werk nie, maar wil hê sy liefde moet meer en meer oorvloedig word in die Filippensegemeente wat in werklike konflikte vasgevang is. Vandag is dit die leser wat die performatiewe effek van die fyn retoriek in hierdie brief mag ervaar. Gelowiges in konflik word geroep om die unieke opbou van die grootste moontlike makrostruktuur in die brief raak te sien. Hulle word naamlik geroep om Christus self te ken, die impak van sy liefde te beleef, daarvoor te bid en dit te fasiliteer in ander se lewens. In hierdie opsig kan konflik in die gemeentebousituasie uitdagings en geleenthede vir groei tot eer van God bied.

\section{Bibliografie}

ALEXANDER, L. 1989. Hellenistic letter-forms and the structure of Philippians. Journal for the Study of the New Testament, 37:87-101.

BATEMAN, H.W. 1998. Were the opponents at Philippi necessarily Jewish? Bibliotheca Sacra, 155(617):39-61, Jan.-Mar. 
BLACK, D.A. 1995. The discourse structure of Philippians: A study in textlinguistics. Novum Testamentum, 37(1):16-49.

BRAUNE, D.D. 1980. The epistle of Paul to the Philippians. (In Lange, J.P., ed. Commentary of the Holy Scriptures, critical, doctrinal and homiletical. Michigan : Zondervan. p. 11-76.)

BREED, D.G. \& JORDAAN, G.J.C. 2000. Verandering van die moreel-etiese situasie in Suid-Afrika in die lig van die kenmotief in 2 Petrus 1:3-4. In die Skriflig, 34(2):207-229.

BURGER, C. 1995. Gemeentes in transito. Vernuwingsgeleenthede in 'n oorgangstyd. Kaapstad : Lux Verbi.

BYBEL. 1957. Die Bybel: dit is die ganse Heilige Skrif wat al die kanonieke boeke van die $\mathrm{Ou}$ en die Nuwe Testament bevat. Kaapstad : Bybelgenootskap van Suid-Afrika.

DAVIS, C.W. 1999. Oral Biblical criticism. The influence of the principles of orality on the literary structure of Paul's epistle to the Philippians. Sheffield : Sheffield Academic Press.

DEIST, F.E. 1994. Onlangse konsepte in teksuitleg en hulle konsekwensies vir die (gereformeerde) teologie. In die Skriflig, 28(2):165-178.

DU PLOOY, A. le R. 1991. 'n Inleidende perspektief oor die aard en die gesag van die belydenisskrifte. In die Skriflig, 25(1):71-95.

DU PLOOY, A. le R. 1998. The keys of the kingdom as paradigm for building up the church in Reformed church government. In die Skriflig, 32(1):53-68.

DU PLOOY, J.L. \& VENTER, C.J.H. 1996. Gereformeerde gemeente-opbou? 'n Evaluering van bestaande definisies binne die geledere van die Gereformeerde Kerke in Suid-Afrika. In die Skriflig, 30(3):343-364.

DU TOIT, A.B. 1992. Retoriek, retoriese analise en prediking. In die Skriflig, 26(4):465-477.

FENTON, G. 1997. A crash course in conflict. (In Shelley, M., ed. Growing your church through training and motivation: 30 strategies to transform your ministry. Library of leadership development. Minneapolis : Bethany House. p. 163-167.)

FERGUSON, S.B. 1997. Let's study Philippians. Edinburgh : Banner of Truth.

FUNK \& WAGNALLS, 1980. Funk and Wagnalls standard dictionary. New York : Lippincott \& Ceowell.

HANSEN, D. 1998a. Love hurts. (In Hansen, D. \& Goetz, D.L. The power of loving your church: leading through acceptance and grace. The pastor's soul series. Library of leadership development. Minneapolis : Bethany House. p. 99-104.)

HANSEN, D. 1998b. What's love got to do with it? (In Hansen, D. \& Goetz, D.L. The power of loving your church: leading through acceptance and grace. The pastor's soul series. Library of leadership development. Minneapolis : Bethany House. p. 39-53.)

HAWTHORNE, G.F. 1983. Word Biblical commentary. Philippians. Waco : Word.

HAYES, J.H. \& HOLLADAY, C.R. 1987. Biblical exegesis. A beginner's handbook. Atlanta : John Knox.

HENDRIKSEN, W. 1962. Philippians. New Testament Commentary. London : The Banner of Truth Trust.

HENDRIKSEN, W. 1988. New Testament commentary. Philippians, Collossians \& Philemon. Edinburgh : Banner of Truth.

HENRY, M. 1996. Matthew Henry's commentary on the whole Bible. (In Libronix digital library system 2001.) [CD-ROM.]

HOMER, A.K. 1984. Philippians. (In Gaebelein, F.E., ed. The expositor's Bible commentary. Michigan : Zondervan. p. 95-159.) 
HOULDEN, J.L. 1977. Paul's letters from prison. London : Penguin.

LEAS, S. 1997. The ten most predictable times of conflict. (In Shelley, M., ed. Leading your church through conflict and reconciliation: 30 strategies to transform your ministry. Library of leadership development. Minneapolis : Bethany House. p. 45-54.)

LENSKI, R.C.H. 1961. The interpretation of St. Paul's Epistles to the Galations, to the Ephesians and to the Philippians. Minneapolis: Augsburg Publishing House.

LÖH, I. \& NIDA, E.A. 1979. A translators handbook on Paul's letter to the Philippians. Stuttgart : United Bible Societies.

LOUW J.P. \& NIDA, E.A.1989. Greek-English lexicon of the New Testament, based on semantic domains. (In Libronix digital library system 2001.) [CD-ROM.]

MAYS, J.L. 1996. Harper's Bible commentary. (In Libronix digital library system 2001.) [CD-ROM.]

MÜLLER, J.A.C. 1991. The new international commentary on the New Testament. The Epistle of Paul to the Philippians. Michigan : Eerdmans.

NEL, M. 1994. Gemeentebou. Halfweg Huis : Orion.

O'BRIEN, P.T. 1977. Introductory thanksgivings in the letters of Paul. Leiden : Brill.

OOSTENBRINK, J.W. \& LOTTER, G.A. 1999. Gereformeerde spiritualiteit as korporatiewe spiritualiteit. In die Skriflig, 33(3):367-383.

OSIEK, C. 2000. Abingdon New Testament Commentaries. Philippians Philemon. Nashville : Abingdon.

PETERLIN, D. 1994. Paul's letter to the Philippians in the light of the disunity in the church. Tyndale Bulletin, 45(1):207-210.

PETERLIN, D. 1995. Paul's letter to the Philippians in the light of the disunity in the church. Leiden : Brill.

POP, F.J. 1957. Bijbelse woorden en hun geheim (vol. 1). Gravenhage : Boekencentrum N.V.

PORTER, J.T. \& REED, J.T. 1998. Philippians as a macro-chiasm and its exegetical significance. New Testament Studies, 44(2):213-231.

PRESTON, G.D. 1997. Staying close to your enemies. (In Shelley, M., ed. Growing your church through training and motivation: 30 strategies to transform your ministry. Library of leadership development. Minneapolis : Bethany House. p. 163-167.)

PRETORIUS, E.A.C. 1995. New trends in reading Philippians: a literature review. Neotestamentica, 29(2):273-298.

PRETORIUS, E.A.C. 1998. Role model for a church: Typifying Paul's letter to the Philippians. Neotestamentica, 32(2):547-571.

REED, J.T. 1999. The cohesiveness of discourse: Towards a model of linguistic criteria for analysing New Testament discourse. (In Reed, J.T., ed. Discourse analysis and the New Testament. Approaches and results. Sheffield : Sheffield Academic Press. p. 28-46.)

RIENECKER, F. \& ROGERS, C.L. 1980. A linguistic key to the Greek New Testament. Michigan : Zondervan.

ROBERTSON, A.T. 1998. Word Pictures in the New Testament. (In Libronix digital library system 2001.) [CD-ROM.]

SWIFT, R.C. 1984. The theme and structure of Philippians. Bibliotheca Sacra, 141(463):234-254, Jul.-Sep.

TELBE, M. 1994. The sosiological factors behind Philippians 3:1-11 and the conflict at Philippi. Journal for the Study of the New Testament, 55:97-121.

VAN DEVENTER, H.J.M. 1999. Retoriese kritiek en die interpretasie van die Ou Testament. In die Skriflig, 33(4):447-467. 
VENTER, P.M. 1997. Intertekstualiteit, kontekstualiteit en Daniël 9. In die Skriflig, 31(4):327-346.

VINE, W.E. 1981. Vine's expository dictionary of Old and New Testament words. (In Libronix digital library system 2001.) [CD-ROM.]

WUEST, K.S. 1997. Wuest's word studies in the Greek New Testament. (In Libronix digital library system 2001.) [CD-ROM.]

\section{Kernbegrippe:}

gemeentebou

konflikhantering

oorvloedige liefde

retoriese kritiek

\section{Key concepts:}

abundant love

building up of a congregation

conflict management

rhetorical criticism 